\title{
Flow Pattern and Residence Time of Groundwater within Volta River Basin in Benin (Northwestern Benin)
}

\author{
Wèré Gédéon Sambiénou ${ }^{1 *}$, Laurence Gourcy², Abdoukarim Alassane1, Christophe Kaki³ \\ Yao Yelidji Joël Tossou ${ }^{4}$, Daouda Mama ${ }^{1}$, Moussa Boukari' ${ }^{1}$, Kamel Zouari ${ }^{5}$ \\ ${ }^{1}$ Laboratory of Applied Hydrology, University of Abomey-Calavi, Cotonou, Benin \\ ${ }^{2}$ BRGM, Orleans, France \\ ${ }^{3}$ Department of Science and Earth, University of Abomey-Calavi, Cotonou, Benin \\ ${ }^{4}$ Directorate of Water Resources (DGEau), Cotonou, Benin \\ ${ }^{5}$ Laboratory of Radio-Analyses and Environment, National Engineering School of Sfax, Sfax, Tunisia \\ Email: *ged.sambienou15@gmail.com
}

How to cite this paper: Sambiénou, W.G., Gourcy, L., Alassane, A., Kaki, C., Tossou, Y.Y.J., Mama, D., Boukari, M. and Zouari, K. (2018) Flow Pattern and Residence Time of Groundwater within Volta River Basin in Benin (Northwestern Benin). Journal of Water Resource and Protection, 10, 663-680. https://doi.org/10.4236/jwarp.2018.107038

Received: February 10, 2018

Accepted: July 8, 2018

Published: July 11, 2018

Copyright $\odot 2018$ by authors and Scientific Research Publishing Inc. This work is licensed under the Creative Commons Attribution International License (CC BY 4.0).

http://creativecommons.org/licenses/by/4.0/

\begin{abstract}
The knowledge about groundwater flow conditions within Volta river basin in Benin, has restricted information coming to piezometry, water storage time, water path, and water quality. A good groundwater resources assessment of this sudano-sahelian area, is a huge condition for the sustainable management of water resources, which since the part of the 20th century is facing a severe drought that leads to a greater aridity. This article provides a summary with the main elements of carbon isotope $\left({ }^{13} \mathrm{C}\right.$ and $\left.{ }^{14} \mathrm{C}\right)$ as well as tritium $\left({ }^{3} \mathrm{H}\right)$ coupled with hydrogeological and hydrochemical data. The goal is to improve the initial water recharging and the groundwater flow system within the aquifer. Two main results can be produced from the groundwater chemistry. First, the interactions between groundwater and clay minerals related to the residence time of groundwater are indicated by a slight evolution of $\mathrm{Ca}-\mathrm{HCO}_{3}$ and $\mathrm{Ca}-\mathrm{Mg}-\mathrm{HCO}_{3}$ to $\mathrm{Na}-\mathrm{HCO}_{3}$. Beside that towards water types $\mathrm{Cl}-\mathrm{NO}_{3}$ indicates the anthropogenic influence on groundwater, related to agricultural activities and sanitation conditions. The carbon-14 activity measured on the TDIC is between 17.29 and $85.47 \mathrm{pmC}$. Therefore, it contains some samples covering a wide period of time from now to the Holocene implying a continuous system recharging over time. All the data confirm the assumption of a homogeneous, largely unified aquifer system with a multi-layer structure, but it also points out the low resource sustainability and a strong anthropogenic contamination of the most superficial horizons.
\end{abstract}




\section{Keywords}

Hydrochemistry, Radiocarbon, Recharging, Residence Time, Dating, Volta River Basin in Benin

\section{Introduction}

Groundwater is the main source of water for domestic and other uses in many rural and urban areas of the Volta river basin in Benin [1], because of the scarcity of available surface water resources in the region. In addition, surface waters that are often highly polluted were the root of Guinea worms, infestations and cholera [2].

Since then, most groundwater has been protected from surface activities; indeed it is often considered to be a higher-quality water that does not need treatment before use.

However, it is currently threatened by various sources of contamination. Over the past two decades, this basin has been experiencing a significant economic boom, with an increase of agricultural activity, coupled with a strong population growth. According to the fact that water is a huge part of this development it is necessary to acknowledge about the quality of this resource [3].

The knowledge of water flow conditions within the aquifers of this basin is relatively limited with very little information on piezometry, recharging processes, residence time and water quality.

So, a better assessment of groundwater resources in this area is a strategic point for the sustainable management of water resources, which since the mid-twentieth century is experiencing drought persistence leading to increase climate aridity [4] [5].

This problem mainly affects the surface but certainly also the recharging of groundwater. To be able to know about the evolution of water resources, recent research, under the aegis of the technical cooperation of the International Atomic Energy Agency (IAEA) has led to the application of isotopic technical, which helped acquire data relating to groundwater origin, its flow path and the residence time.

This article is a synthesis of results using isotopes of carbon $\left({ }^{13} \mathrm{C}\right.$ and $\left.{ }^{14} \mathrm{C}\right)$ and tritium $\left({ }^{3} \mathrm{H}\right)$ couple with hydrogeological and hydrochemical data.

\section{Geological and Hydrogeological Setting}

\subsection{Study Area and Hydroclimatology}

The Volta river basin in Benin, covers an surface area of $13,590 \mathrm{~km}^{2}$, or $13 \%$ of the national territory (Figure 1) and $3.4 \%$ of the total area of the basin shared with Burkina Faso (43\%), with Ghana (42\%), (15\%), with Togo, (2\%) with Mali and Ivory Coast [4] [5] [6] [7] [8]. 


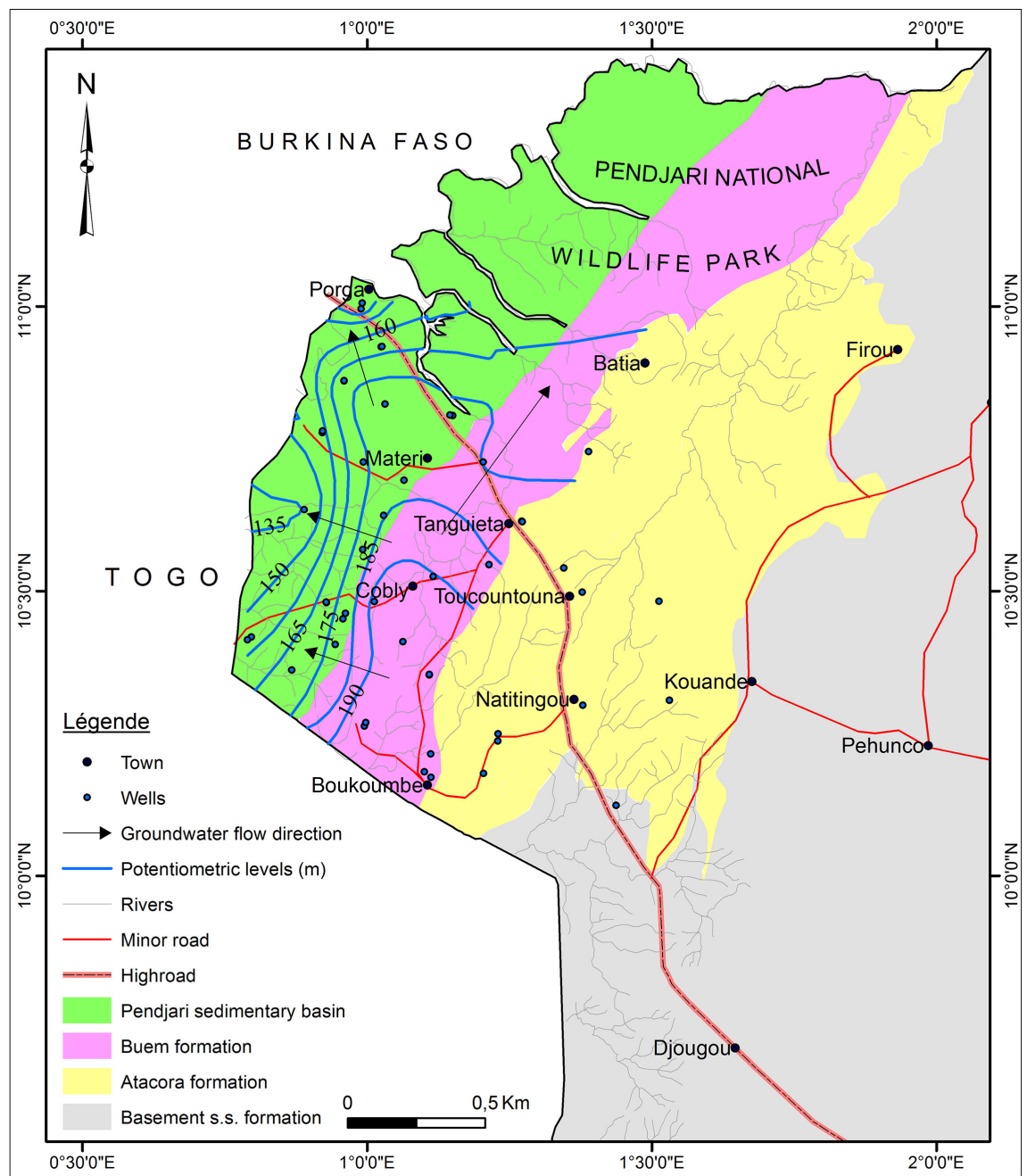

Figure 1. Map of the study area showing the location of the sampled boreholes and geologic and hydrologic information.

Located in the Sudano-Sahelian zone, this basin is between $9^{\circ} 30^{\prime}$ and a latitude of $11^{\circ} 30^{\prime}$ North and $0^{\circ} 45^{\prime}$ and a longitude of $2^{\circ} 03^{\prime}$ East (Figure 1).

It is characterized by a relatively contrasting geomorphology, made up of hill chains to the east and center, and a lowland to the west.

Its altitude gradually increases from $160 \mathrm{~m}$ on average in the Pendjari plain to the West, to a maximum of $650 \mathrm{~m}$ on the Atacora range to the East.

Half of the North area of the basin is occupied by the Pendjari National Park and the population's rate, in majority rural, is increasing around the park [9] [10].

The climate is characterized by a unique rainy season which lasts from May to October [11] [12]. The annual rainfall average recorded at the synoptic meteorological station of Natitingou for the period from 1979 to 2009 is $1173 \mathrm{~mm}$, with an average temperature of $27.4^{\circ} \mathrm{C}$.

The annual evapotranspiration average of $1494 \mathrm{~mm}$ is much higher than the annual rainfall [12]. The Pendjari River is characterized by a steady flow, with a 
minimum flow of $1 \mathrm{~m}^{3} / \mathrm{s}$ from March to April and a maximum flow of $300 \mathrm{~m}^{3} / \mathrm{s}$, in September [11].

They have decreased from 0 to $238 \mathrm{~m}^{3} / \mathrm{s}$ in Porga and from 0 to $25 \mathrm{~m}^{3} / \mathrm{s}$ in Tiélé, which confirms a flow deficit due to the rainfall recession and large losses of water per year through evaporation [4] [13].

\subsection{Geology and Tectonics}

The volta river basin in Benin is shrouded essentially in a geological set called of external units (Figure 2) [14]-[21]. It's an old Precambrian base cover (Proterozoic Terminal) s.s. (Figure 2(a)). It is folded with a tabular part that more or less changed by pan-African organ (Figure 2(b)). In the west, the sedimentary sequences are monoclinic and are the sedimentary basin of Pendjari. They become

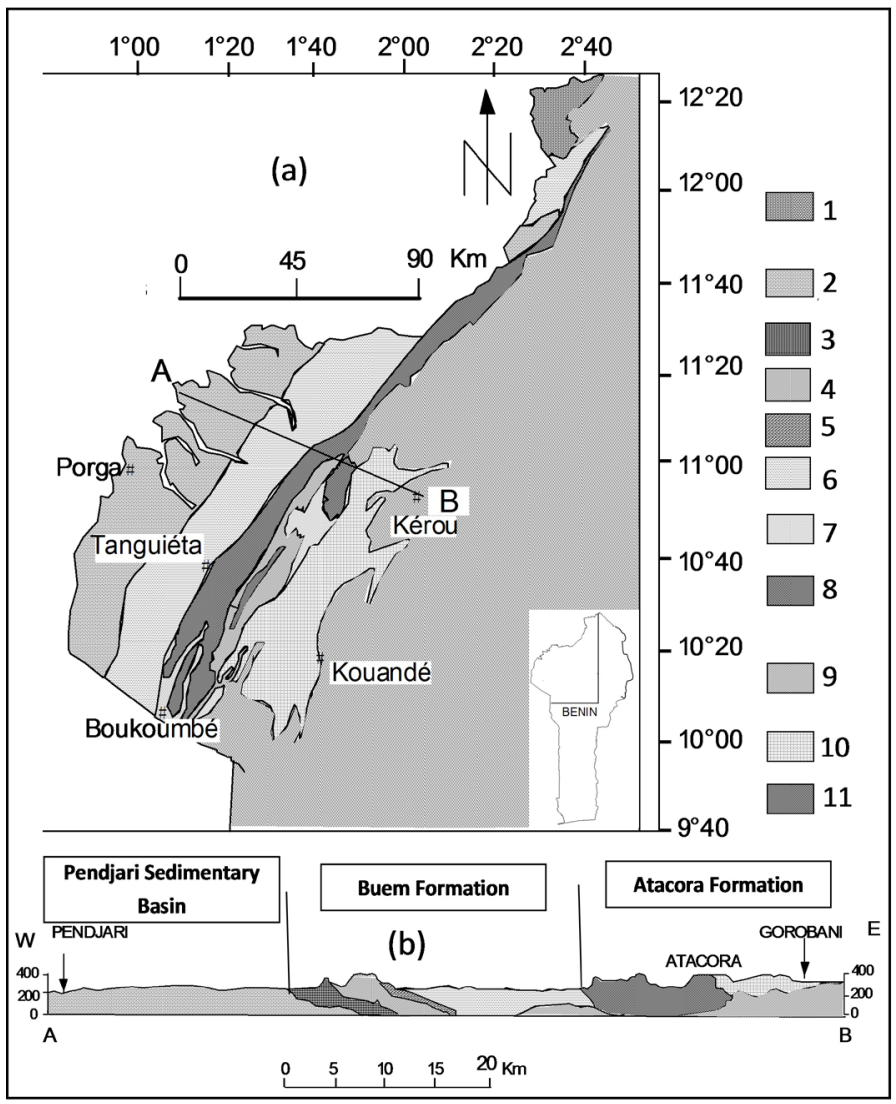

Figure 2. Regional geological map (a) of the Volta river basin in Benin, with the geological cross section AB; (b) (According to [15] [17] [18]): Paleozoic: 1-Volta sedimentary Basin (sandstones, argillites, quartzites); Upper Proterozoic: 2-Pendjari sedimentary Basin (argillites, fine sandstones); Upper Proterozoic (Panafrican orogeny) Buem Formation: 3-Buem serie (Jasper); 4-Buem serie (fine and medium quartzous sandstones); 5-Buem serie (basic rocks); 6-Buem serie (sandstone, quartzites); Atacora Formation: 7-Kandé serie (schists, quartzites); 8-Korontière serie (fine quartzites); 9-Kanson serie (schists, quartzites); 10-Kouandé serie (quartzites, schists); Middle Proterozoic (updated by panafrican orogeny): 11-Basement s.s. Formations (orthogneiss, gneiss and micaschists into the study area). AB line: position of the geological cross section $\mathrm{AB}$. 
increasingly folded and changed as we move on towards the east [15] [21] [22] [23]. Then they are gather together in two distinct parts according to the way they wrinkle and the way they change. We have: Buem formation, the less damaged one, and the Atacora formation the most affected. That one is overlapped by basement formations and overlapped also Buem formation which overlaps the sedimentary basin of Pendjari. The metamorphism that has affected Buem and Atacora is a lower degree than the one that affected the basement s.s.

The Atacora range is the most prominent range in the basin. It is oriented NNE-SSW [21] [24] in [25]. Buem formation is made up of argillites, siltites, quartzitic sandstones, hematic rocks and sericite schists, and also with a set of jasper, and basic magmatic rock [16] [26] [27] [28]. In addition, Atacora formation has a serie of schists and quartzites aquifers. In the West the tabular covers of terminal Proterozoic are free of any metamorphism and are composed by argillites, siltites and with highly indurated sandstones (Figure 2). Finally, the basement formations are constituted of orthogneiss, ordinary gneiss and micaschists in the study area.

So, the study area has four geological sub-units [15] [17] [18] namely, the sedimentary basin of Pendjari, Buem formation, Atacora formation and the basement s.s from West to East. Those four formations match respectively with four aquifers with the same names (Figure 3 ) that have been studied. The Buem formation is very similar to the aquifer of Pendjari which is generally considered to be unremitting and free-flowing at least in its affected surface area. The two

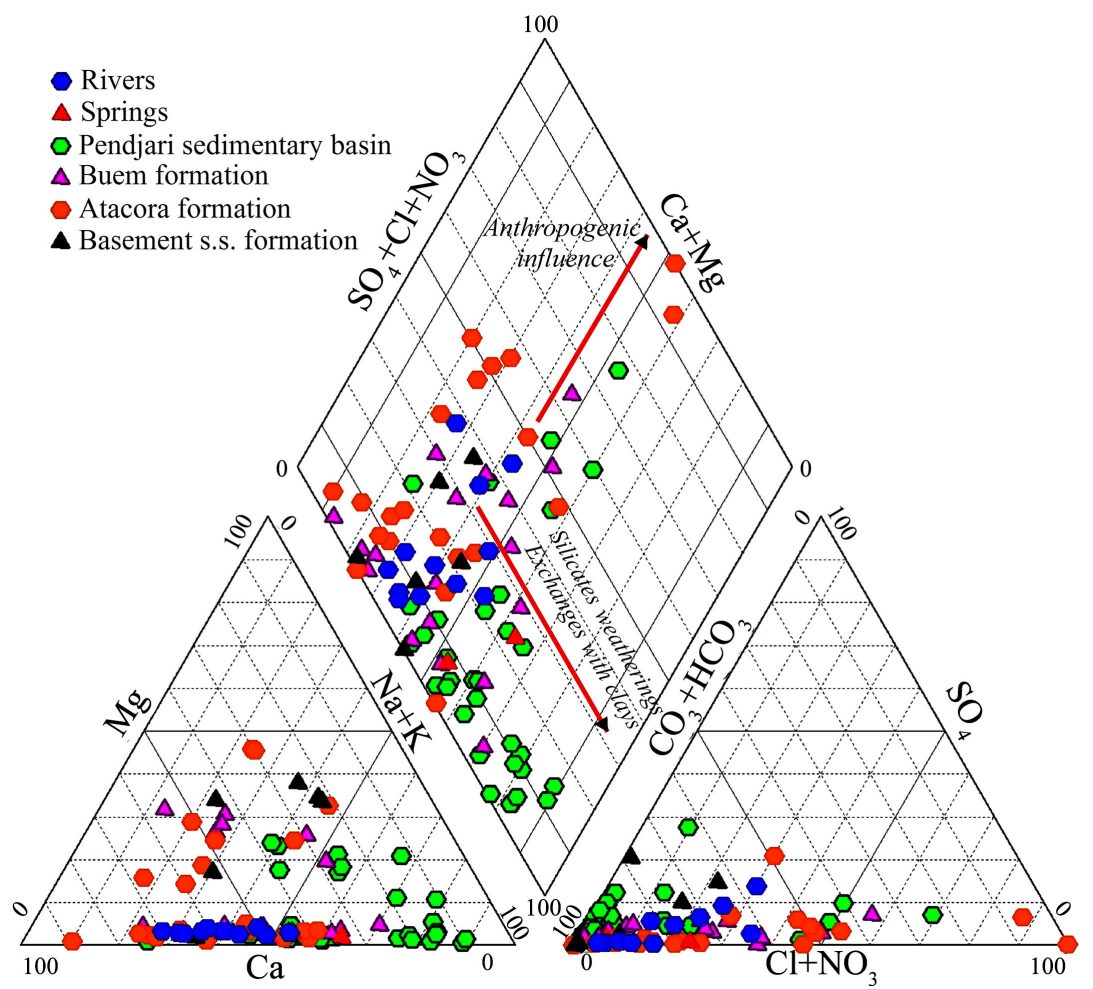

Figure 3. Volta river basin in Benin waters positions in the major ions (meq/L) Piper diagram. 
one (Atacora and the basement s.s. formations) are so discontinuous with an aquifer of fractures crowned by an aquifer of alterites. The first porosity is destroyed in most aquifers by consolidation and case-hardening [29]. Nevertheless, due to the intensity of surface deterioration and brittle tectonics affecting all of these formations, the aquifers mentioned are likely to be in hydrodynamic (lateral hydraulic interconnection), and hence hydrochemical, interconnection through not only the superficial alterites, but also more or less deep and open fractures.

\subsection{Hydrogeology}

This region hydrogeology is not well known so that only few groundwater exploration projects have been carried on in this river. And the conditions are very complex as showed by the data providing from the existing drillings and the wells. The depth of the water changes throughout the basin, but is generally shallow, from $1.7 \mathrm{~m}$ to $84 \mathrm{~m}$ with the catchments depth from $31 \mathrm{~m}$ to $104 \mathrm{~m}$ [12]. The aquifer of the deteriorated region and the fracture zones are the major aquifers. As a unit, the altered zone extends about $4 \mathrm{~m}$ to $20 \mathrm{~m}$ thickness [29] [30] and in most of the village, it is built to supply water through wells digged by hand [31], but most of the wells dry up during the dry season. Fracture zones are developed below the soil surface in the bedrock with $20 \mathrm{~m}$ of depths or more [32]. They are mostly vertically close, narrow and linear. Groundwater is in the control of fractures [29] [30] [32] and generally occurs under semi-confined conditions, which may exist in places where static water level (SWL) diverse from 1 to $20 \mathrm{~m}$ below the earth surface [29]. The specific capacities (Q/s) of boreholes in the catchment range from 0.01 to $5.5 \mathrm{~m}^{3} / \mathrm{h} / \mathrm{m}$ and the transmissivity varies between $10^{-6}$ and $10^{-2} \mathrm{~m}^{2} / \mathrm{s}$ [12].

\section{Materials and Methods}

A total of 93 water samples were taken from the whole Benin's Volta River, of which 30 were collected during the February-March 2012 campaign and 63 during the October-November 2013 season (Figure 1). Furthermore, monthly rainfall samples were obtained from the pluviograph of the ASECNA synoptic station at Natitingou. Since the results are almost the same we put them together, in this article for a better study. Going into this result, 34 samples come from the Pendjari Sedimentary Basin, 18 from Buem Formation, 21 from the Atacora Formation, 6 from the basement formation s.s, 2 from the springs and 12 from the rivers.

Before the measurements were taken, a pump was used to drill the wells till the $\mathrm{pH}$ stabilization, the electrical conductivity, and the Temperature is known. An HI 9828 multi-parameter was used for it. Then, the water samples were collected and stored in high-density, $1000 \mathrm{ml}$ polyethylene bottles with poly-seal stoppers. The depths of the water table were measured in the wells using a WL500 piezometric probe. The Alkalinity was measured out by volumetric titra- 
tion using chemical kits. To record all data and the sampling points altitudes the global positioning system (GPS) named Garmin GPSMAP 76 was used.

Each sample was tested at the Radio-Analysis and Environment Laboratory (Sfax, Tunisia) to determine the major components $\left(\mathrm{Ca}^{2+}, \mathrm{Mg}^{2+}, \mathrm{Na}^{+}, \mathrm{K}^{+}, \mathrm{Cl}^{-}\right.$, $\mathrm{SO}_{4}^{2-}, \mathrm{HCO}_{3}^{-}, \mathrm{CO}_{3}^{2-}$ Nitrates $\left.\left(\mathrm{NO}_{3}^{-}\right)\right)$and stable isotopes $\left({ }^{2} \mathrm{H}\right.$ and $\left.{ }^{18} \mathrm{O}\right)$, but $\mathrm{HCO}_{3}^{-}, \mathrm{CO}_{3}^{2-}$ was tested by Liquid-Phase Chromatography (ILC), equipped with IC-Pak TM CM/D columns for cations, using EDTA and nitric acid as eluent. For anions a Metrohm chromatograph, equipped with CI SUPER-SEP using phthalic acid and acetonitril acid as eluent was used for the test with an accuracy of $2 \%$. The overall detection limit of the ions was $0.04 \mathrm{mg} / \mathrm{l}$. $\mathrm{HCO}_{3}^{-}$et $\mathrm{CO}_{3}^{2-}$ contents were analyzed by titration with $0.1 \mathrm{~N} \mathrm{HCl}$ acid. All the results were tested for the ionic charge equilibrium according to [33]. The error margin between cations and anions is $\pm 5 \%$, meaning that all the results are valid for interpretation. Total dissolved solids (TDS) are measured by evaporating $100 \mathrm{ml}$ of water sample for $24 \mathrm{~h}$ at $105^{\circ} \mathrm{C}$. The isotopic tracers $\left({ }^{18} \mathrm{O}\right.$ and $\left.{ }^{2} \mathrm{H}\right)$ were used to bring more light to the identified ions and other possible processes that control their concentration in the basin.

Those Stable isotopes $\left({ }^{2} \mathrm{H}\right.$ and $\left.{ }^{18} \mathrm{O}\right)$ were analyzed using an LGR DLT 100 laser absorption spectrometer [34] with the same measurements accuracy of $\pm 1.5 \%$.

For the second campaign, 45 samples were selected for tritium analysis at Isodetect $\mathrm{GmbH}$ Laboratory. Those tritium samples were enriched by electrolytic enrichment and tested by the liquid scintillation counting method [35]. It is estimated by tritium unit (TU) matching with one atom for $10^{18}$ hydrogen atom.

Among these 45 samples, 11 were analysed by carbon isotopes at the Energy and Sustainability Research Institute in Groningen during the third campaign. While carbon-13 was tested with a mass spectrometer, Carbon 14 analysis was performed using the liquid scintillation counting method. They are estimated as percent of modern carbon ( $\mathrm{pmC}$ ) [36] with an average analytical error margin of $0.2 \mathrm{pmC}$. For carbon-13, the results are estimated in percentage (\%) according to Pee Dee Belemnite's rule with an accuracy of $\pm 0.2 \%$.

\section{Results and Discussion}

\subsection{Water Chemistry}

The results about groundwater chemistry and its stables isotopes, were related. The groundwaters within volta river basin in Benin are characterized by $\mathrm{Ca}^{2+}$ and $\mathrm{Na}^{+}$and mainly $\mathrm{HCO}_{3}^{-}$ions according to Piper diagram (Figure 3 ). These components are the same as those in the other volta's sub-basins by [29] [37] [38].

Two main conclusions can be draw from this diagram. Firstly, the evolution from $\mathrm{Ca}-\mathrm{HCO}_{3}$ or $\mathrm{Ca}-\mathrm{Mg}-\mathrm{Na}-\mathrm{HCO}_{3}$ to $\mathrm{Na}-\mathrm{K}-\mathrm{HCO}_{3}$ show more interactions between groundwater and clay minerals due to isomorphic substitutions and exchange processes of cation and/or alteration of silicates [29] [37] [38] [39] [40]. This phenomenon is related to the mineralization of groundwater resi- 
dence time in the aquifer as suggested by [40] in the Taoudeni sedimentary ba$\sin$.

Therefore it could be considered as an indirect indicator to show how long water can last in rock. Indeed, petrographic analysis and X-ray diffraction of sample of rocks show that the mineralization of Pendjari's sedimentary basin is highly composed by plagioclase sodium and Quartz with low proportions of chlorite, muscovite, calcite, talc and zeolite. While the mineralization of the rocks of the Buem formation is dominated by plagioclases of sodium, calcite, titanium and iron oxide [16], the formations of Atacora, according to [19], are dominated by quartz, muscovite and chlorite. And the basement s.s formations are dominated by plagioclases, quartz and muscovite.

Secondly, $\mathrm{HCO}_{3}$ evolution to $\mathrm{Cl}-\mathrm{NO}_{3}$ point out the anthropogenic influence on groundwater by the intensive use of chemical fertilizers in agriculture by [41].

\subsection{Tritium Content in Groundwater}

The Variations of tritium content provide an overview of the local recharging mechanism [29] [38]. The tritium values measured in the groundwater samples of the Volta river basin in Benin (Table 1) are between 0.7 and 3.9 TU with an average value of 1.6 TU. Those of surface water are between 2.7 and $3.4 \mathrm{TU}$ for an average of $2.9 \mathrm{TU}$ and they indicate very recent water or tritium content that has decayed over time because its half-life of radioactive lasts 12.32 years [42].

The tritium values obtained from most of groundwater samples are similar to current meteorological water values. Those higher than $1 \mathrm{UT}$ indicate a recent recharging by modern rains, resulting in equilibrium between groundwater and the atmosphere contaminated by nuclear tests initiated around 1950 [33] [41].

However, some samples with tritium values less than 1TU may correspond to older groundwater, indicating a recharging before 1952 [38] [43] [44]. The corresponding wells located in the sedimentary part of Pendjari basin and characterized by low tritium values $(<1 \mathrm{TU})$ and high TDS values $(>450 \mathrm{mg} / \mathrm{L})($ Figure 4) are interpreted as a residence time of groundwater more or less long. BV04-02, BV06-02, BV09-02, BV11-02, BV12-02, BV13-02, BV14-02, BV70-02 correspond respectively to the drilling waters of Nanagade, Datori, Tapoga, Porga, Materi, Namoutchaga and BV17-02 from the Atacora formation correspond to the Batia drilling water. All of these define the discharge area as shown by the piezometry (Figure 1). This seems to be in agreement with the hydrochemical results, which showed the first main conclusion of groundwater evolution.

\subsection{Groundwater Age}

\subsubsection{Carbon Isotopes}

The carbon isotopes are determined in the aquifer system in order to get more information on residence time of groundwater and to characterize the water mixing processes and the chemical reactions occurring there [45]. 
Table 1. Isotopic characteristic of analyzed samples of the Volta river basin in Benin.

\begin{tabular}{|c|c|c|c|c|c|c|c|c|c|c|c|}
\hline Sample & Aquifer & $\mathrm{Z}$ & Depth & TDS & $\delta{ }^{2} \mathrm{H}$ & $\delta{ }^{18} \mathrm{O}$ & ${ }^{3} \mathrm{H}$ & ${ }^{3} \mathrm{H}$ & ${ }^{13} \mathrm{C}$ & ${ }^{14} \mathrm{C}$ & ${ }^{14} \mathrm{C}$ \\
\hline number & (formation) & $(\mathrm{m})$ & (m) & $(\mathrm{mg} / \mathrm{L})$ & (\%o V-s & MOW) & (TU) & $\pm 2 \sigma$ & (PDB) & $(\mathrm{pmC})$ & $\pm 2 \sigma$ \\
\hline BV04-02 & Pendjari & 183.6 & 35.37 & 525.5 & -32.96 & -5.17 & 0.70 & & -12.96 & 44.75 & 0.22 \\
\hline BV09-02 & Pendjari & 212.8 & 50.33 & 632.1 & -28.35 & -5.04 & 0.70 & & -11.19 & 85.47 & 0.31 \\
\hline BV12-02 & Pendjari & 159.2 & 51 & 881.1 & -36.58 & -5.81 & 0.70 & & -11.59 & 44.65 & 0.22 \\
\hline BV13-02 & Pendjari & 211.7 & 37.5 & 467.6 & -28.51 & -4.90 & 0.70 & & -14.43 & 17.29 & 0.14 \\
\hline BV11-02 & Pendjari & 198.8 & 33.77 & 746.8 & -23.60 & -3.94 & 0.80 & & -9.33 & 61.09 & 0.26 \\
\hline BV58-02 & Pendjari & 195 & 13 & 346.5 & -23.81 & -4.48 & 0.80 & & -11.94 & 33.68 & 0.19 \\
\hline BV70-02 & Pendjari & 202.3 & 47 & 867.4 & -21.97 & -3.56 & 0.80 & & -11.09 & 28.25 & 0.18 \\
\hline BV14-02 & Pendjari & 168.8 & 33.5 & 474.7 & -24.30 & -3.97 & 0.8 & & -11.2 & 66.96 & 0.27 \\
\hline BV06-02 & Pendjari & 166.9 & 39.5 & 533.9 & -26.96 & -4.70 & 0.90 & & -11.68 & 83.31 & 0.31 \\
\hline BV50-02 & Pendjari & 233.5 & 32.8 & 201.8 & -23.40 & -4.33 & 1.0 & 0.70 & & & \\
\hline BV07-02 & Pendjari & 200 & 41.66 & 514.5 & -25.16 & -4.72 & 1.00 & 0.70 & & & \\
\hline BV62-02 & Pendjari & 169.3 & 74 & 493.2 & -19.31 & -3.59 & 1.00 & 0.70 & & & \\
\hline BV18-02 & Atacora & 241.6 & 51 & 429.8 & -21.37 & -3.34 & 1.1 & 0.70 & & & \\
\hline BV54-02 & Pendjari & 176.2 & 26 & 302.2 & -33.50 & -5.14 & 1.1 & 0.70 & & & \\
\hline BV65-02 & Pendjari & 249.8 & 31.33 & 439.9 & -24.16 & -4.53 & 1.30 & 0.70 & & & \\
\hline BV71-02 & Pendjari & 216.8 & 14.97 & 75.1 & -20.41 & -3.43 & 3.1 & 0.70 & & & \\
\hline BV51-02 & Pendjari & 159 & 15.01 & 448.7 & -27.65 & -4.65 & 3.9 & 0.70 & & & \\
\hline BV04-01 & Pendjari & 187.4 & 35.37 & 239 & -31.35 & -5.11 & & & & & \\
\hline BV05-01 & Pendjari & 171.9 & 44.58 & 617 & -25.20 & -4.19 & & & & & \\
\hline BV06-01 & Pendjari & 180.2 & 39.5 & 648 & -25.90 & -4.16 & & & & & \\
\hline BV07-01 & Pendjari & 192.9 & 41.66 & 569 & -24.67 & -4.41 & & & & & \\
\hline BV08-01 & Pendjari & 215.3 & 23.93 & 915 & -32.48 & -4.98 & & & & & \\
\hline BV09-01 & Pendjari & 210.6 & 50.33 & 273 & -26.41 & -4.26 & & & & & \\
\hline BV11-01 & Pendjari & 197.9 & 33.77 & 782 & -22.05 & -3.26 & & & & & \\
\hline BV12-01 & Pendjari & 167.3 & 51 & 964 & -35.46 & -5.52 & & & & & \\
\hline BV13-01 & Pendjari & 192.9 & 37.5 & 676 & -28.04 & -4.19 & & & & & \\
\hline BV14-01 & Pendjari & 179 & 33.5 & 567 & -24.28 & -3.21 & & & & & \\
\hline BV49-02 & Pendjari & 199.8 & 9.05 & 466.8 & -23.40 & -4.14 & & & & & \\
\hline BV53-02 & Pendjari & 179.6 & 11.8 & 64.6 & -24.47 & -4.23 & & & & & \\
\hline BV55-02 & Pendjari & 180 & 8.89 & 412.8 & -22.12 & -4.31 & & & & & \\
\hline BV56-02 & Pendjari & 162.7 & 5.5 & 492.3 & -25.14 & -4.36 & & & & & \\
\hline BV57-02 & Pendjari & 198 & 9.65 & 269.6 & -20.74 & -4.07 & & & & & \\
\hline BV66-02 & Pendjari & 186.4 & 1.77 & 78.7 & -23.74 & -4.01 & & & & & \\
\hline BV67-02 & Pendjari & 179.2 & 3.08 & 320.0 & -20.77 & -4.04 & & & & & \\
\hline BV68-02 & Pendjari & 190.4 & 3.08 & 68.7 & -21.90 & -3.89 & & & & & \\
\hline
\end{tabular}


W. G. Sambiénou et al.

\section{Continued}

\begin{tabular}{|c|c|c|c|c|c|c|c|c|c|c|c|}
\hline BV23-02 & Buem & 225.2 & 50.73 & 361.4 & -21.28 & -4.02 & 0.70 & & -14.58 & 52.41 & 0.24 \\
\hline BV72-02 & Buem & 268 & 42.03 & 468.6 & -17.36 & -3.41 & 1.6 & 0.70 & & & \\
\hline BV10-02 & Buem & 189.9 & 30.83 & 416.4 & -23.34 & -4.29 & 1.69 & 0.70 & & & \\
\hline BV64-02 & Buem & 202.3 & 15.05 & 358.7 & -23.53 & -4.04 & 2.7 & 0.70 & & & \\
\hline BV22-02 & Buem & 296 & 27.67 & 110.7 & -20.68 & -3.48 & 2.8 & 0.70 & & & \\
\hline BV15-02 & Buem & 231 & 53.5 & 196.3 & -19.55 & -3.85 & 3.0 & 0.70 & & & \\
\hline BV01-01 & Buem & 240.9 & 24.1 & 717 & -20.86 & -3.49 & & & & & \\
\hline BV03-01 & Buem & 247.3 & 34.65 & 334 & -23.95 & -4.17 & & & & & \\
\hline BV10-01 & Buem & 190.1 & 30.83 & 716 & -22.49 & -4.28 & & & & & \\
\hline BV15-01 & Buem & 227.9 & 53.5 & 239 & -18.79 & -3.10 & & & & & \\
\hline BV22-01 & Buem & 233 & 27.67 & 130.9 & -20.76 & -3.50 & & & & & \\
\hline BV23-01 & Buem & 222.6 & 50.73 & 382 & -22.66 & -4.23 & & & & & \\
\hline BV61-02 & Buem & 225.8 & 5.89 & 130.7 & -21.99 & -4.03 & & & & & \\
\hline BV63-02 & Buem & 247 & 12.1 & 65.7 & -21.62 & -3.69 & & & & & \\
\hline BV73-02 & Buem & 221.6 & 13.3 & 175.1 & -22.93 & -3.61 & & & & & \\
\hline BV74-02 & Buem & 249.9 & 8.48 & 100.6 & -19.79 & -3.87 & & & & & \\
\hline BV76-02 & Buem & 210.8 & 1.77 & 149.0 & -15.70 & -3.14 & & & & & \\
\hline BV79-02 & Buem & 236 & 12.1 & 234.9 & -22.67 & -3.50 & & & & & \\
\hline BV17-02 & Atacora & 235.4 & 70.44 & 498 & -22.36 & -3.61 & 0.9 & 0.70 & -13.37 & 37.51 & 0.2 \\
\hline BV44-02 & Atacora & 419.9 & 41.5 & 171.5 & -19.41 & -3.87 & 1.30 & 0.70 & & & \\
\hline BV46-02 & Atacora & 246.2 & 20.45 & 319 & -22.33 & -3.87 & 1.5 & 0.70 & & & \\
\hline BV29-02 & Atacora & 526 & 42.67 & 19.1 & -21.53 & -4.22 & 2.0 & 0.70 & & & \\
\hline BV21-02 & Atacora & 569.9 & 43.5 & 34.1 & -23.10 & -3.88 & 2.6 & 0.70 & & & \\
\hline BV20-02 & Atacora & 576.1 & 64.66 & 49.2 & -21.83 & -3.56 & 2.7 & 0.70 & & & \\
\hline BV38-02 & Atacora & 647.1 & 48.25 & 14 & -23.00 & -4.17 & 2.9 & 0.70 & & & \\
\hline BV25-02 & Atacora & 427.8 & 40 & 188.5 & -20.48 & -4.00 & 3.2 & 0.70 & & & \\
\hline BV17-01 & Atacora & 239.7 & 70.44 & 539 & -21.77 & -3.40 & & & & & \\
\hline BV18-01 & Atacora & 249 & 51 & 497 & -20.62 & -2.97 & & & & & \\
\hline BV19-01 & Atacora & 536.5 & 34.31 & 22 & -23.10 & -3.93 & & & & & \\
\hline BV20-01 & Atacora & 584.2 & 64.66 & 70.0 & -20.94 & -3.73 & & & & & \\
\hline BV21-01 & Atacora & 550 & 43.5 & 55.6 & -21.44 & -3.88 & & & & & \\
\hline BV25-01 & Atacora & 400 & 40 & 335 & -19.79 & -3.66 & & & & & \\
\hline BV29-01 & Atacora & 515.3 & 42.67 & 19 & -21.24 & -3.83 & & & & & \\
\hline BV30-01 & Atacora & 404.5 & 30.67 & 132.2 & -21.37 & -3.87 & & & & & \\
\hline BV32-01 & Atacora & 617.3 & 36.99 & 33 & -21.26 & -4.14 & & & & & \\
\hline BV42-02 & Atacora & 428.2 & 5.76 & 45.1 & -25.24 & -4.51 & & & & & \\
\hline BV47-02 & Atacora & 232.1 & 4.01 & 584.9 & -19.84 & -3.34 & & & & & \\
\hline BV77-02 & Atacora & 575.8 & 5.8 & 49.2 & -22.74 & -4.36 & & & & & \\
\hline
\end{tabular}




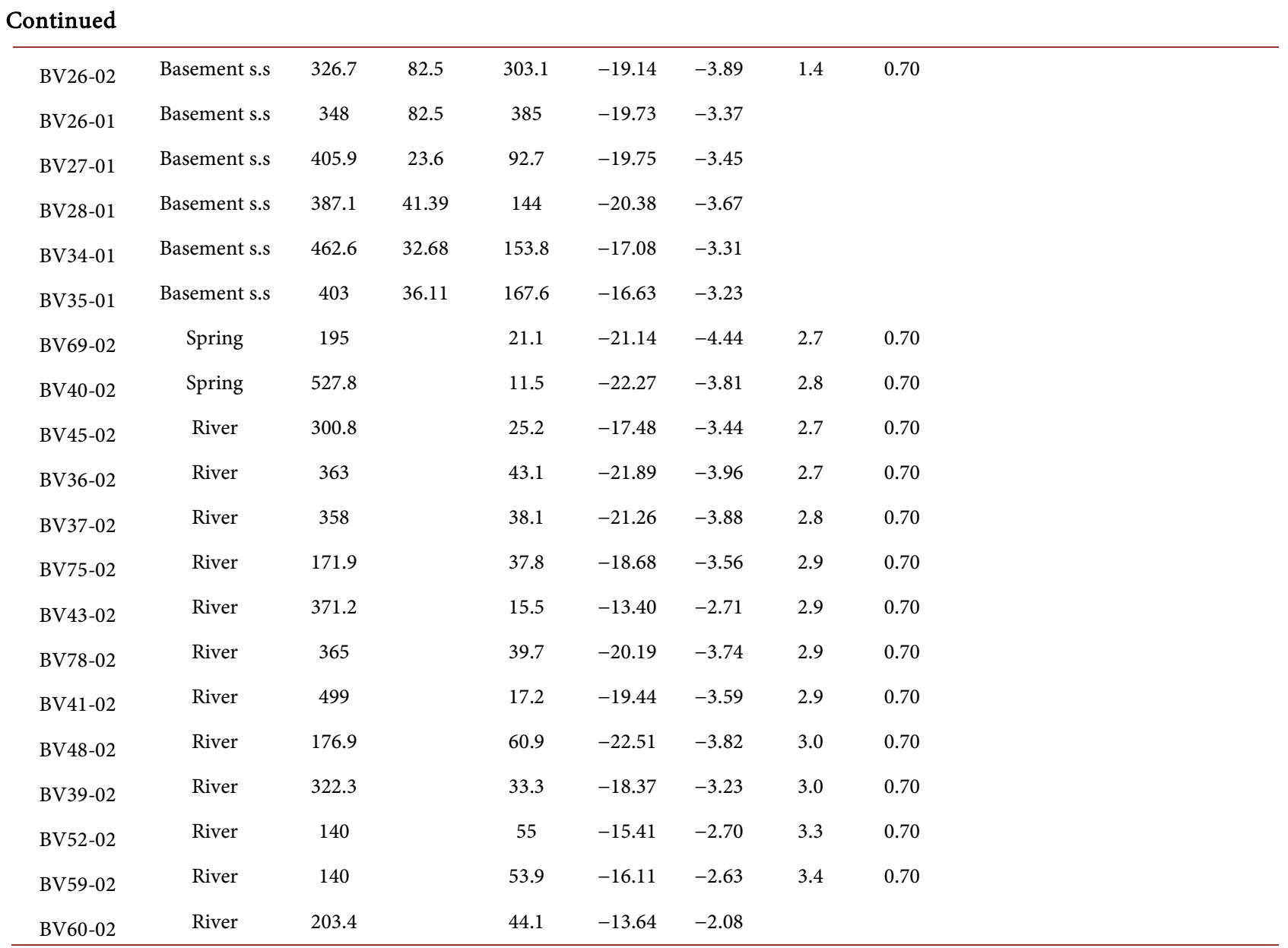

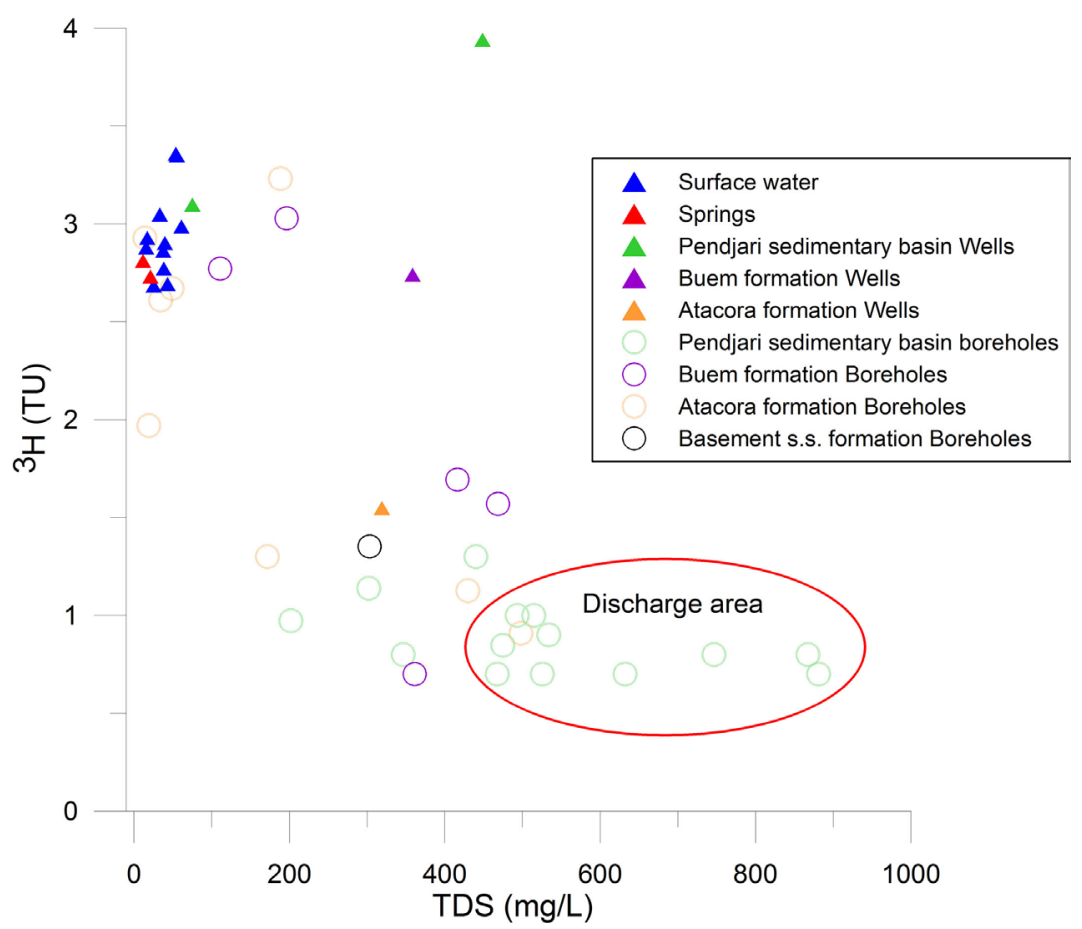

Figure 4. Relation ${ }^{3} \mathrm{H} / \mathrm{TDS}$ in Volta river basin in Benin. 
The values of $\delta^{13} \mathrm{C}$, in \%o vs $\mathrm{PDB}$ and ${ }^{14} \mathrm{C}$ activities, as a percentage of modern carbon $(\mathrm{pmC})$ are given in Table $1 . \delta^{13} \mathrm{C}$ contents are between -14.6 and -9.3 with an average of $-12.1 \%$ vs $\mathrm{PDB}$ while ${ }^{14} \mathrm{C}$ activities is between 17.3 and 85.5 with an average of $50.5 \mathrm{pmC}$. The $\delta^{13} \mathrm{C}$ isotopic fractionation of all samples was corrected to $-25 \%$ o vs $\mathrm{PDB}$ which is the average value between the vegetation cover and the marine carbonate $\left(\right.$ via $\left.\mathrm{CO}_{2}\right)$ [36] [43].

The relationship between ${ }^{14} \mathrm{C}$ and $\delta{ }^{13} \mathrm{C}$ activity (Figure $5(\mathrm{a})$ ) shows three groups of groundwater. Firstly, ${ }^{14} \mathrm{C}$ activity greater than $60 \%$ shows that waters are recent. Secondly, ${ }^{14} \mathrm{C}$ activity between $30 \%$ and $60 \%$ indicates old water or a mixture of old and new water. And a third group with a ${ }^{14} \mathrm{C}$ activity less than $20 \%$ testifies the presence of old water. These results are confirmed by the graph ${ }^{3} \mathrm{H}$ versus ${ }^{14} \mathrm{C}$ of Figure 5 (b).

Indeed, according to [43], when groundwater is very recent, its content in ${ }^{14} \mathrm{C}$ must be close to or greater than $100 \%$, because the $\mathrm{CO}_{2}$ in the soil likely contains thermonuclear ${ }^{14} \mathrm{C}$. Thus, we refer to water that have infiltrated for some decades. The new groundwater can be any age counted in hundreds of years corresponding to the first group. The second group groundwater can be aged in several thousand years. The third group groundwater with more than ${ }^{3} \mathrm{H}$ is aged of several tens of thousands of years.

\subsubsection{Groundwater Age Calculation}

As explained by [46], the term "groundwater age", although practical, may be misleading. It really means the average of a residence time distribution. When a single recharging event occurs in sporadically reconstituted systems, groundwater age becomes definitely synonymous of recharging [40] [46].

Groundwater residence times have been estimated in this article from TDIC ${ }^{14} \mathrm{C}$ activity in 11 samples taken from the sedimentary part of the Benin basin of the Volta. Seven models based on chemical evolution and/or isotopic dilution of ${ }^{13} \mathrm{C} /{ }^{12} \mathrm{C}$ from soil $\mathrm{CO}_{2}$ through interactions in the aquifer environment have been adopted. It is likely that the ages proposed by [47] [48] [49] [50] [51] are generally in agreement and provide similar solutions. The models of IAEA [52] and [53] tend to overestimate the residence times of groundwater.

In this article, the results of ${ }^{14} \mathrm{C}$ activities (Table 2) have been corrected using the [47] model. Indeed, this model provides an adequate estimate of age taking into account the conditions and the moment of the palaeorecharge [54]. The corrections used for the TDIC $\delta^{13} \mathrm{C}$ and soil $\mathrm{CO}_{2}$ and mineral phases are respectively $-21 \%$ and $0 \%$. It is well adapted to the geochemical reactions occurring in the groundwater of the study area. The [47] model assumes a mixing of two poles: $\mathrm{CO}_{2}$ and the aquifer matrix.

Table 2 summarizes the radiocarbon ages obtained for the 11 samples, using the seven kind of correction based on isotopic solutions and the estimate of the gross age. All those correction models suggest Holocene ages. The $1^{\text {st }}$ group is of current age and round up water of the drillings of Dassari, Gouandé, Datori and Tapoga. The $2^{\text {nd }}$ group is a post-Holocene age between 1216 and 8502 years BP. 
It includes water of Namoutchaga, Nambouli, Batia, Porga, Nanagade and Korontiere. And finaly between 10,013 and 14,969 years BP we have the Holocene age, only with the drilling water of Materi.

In short, the data of chemistry (evolution of hydrochemical facies), piezometry and, above all, isotopic data show that the hydrogeological system of the Volta river basin in Benin is made up of sub-units more or less interconnected as indicated in this diagram (Figure 6). The formation of Atacora and the western sector of the Buem, with their reliefs, are the preferential recharging areas. The lowland areas, like the Pendjari sedimentary basin, are the areas of flow or groundwater transit.

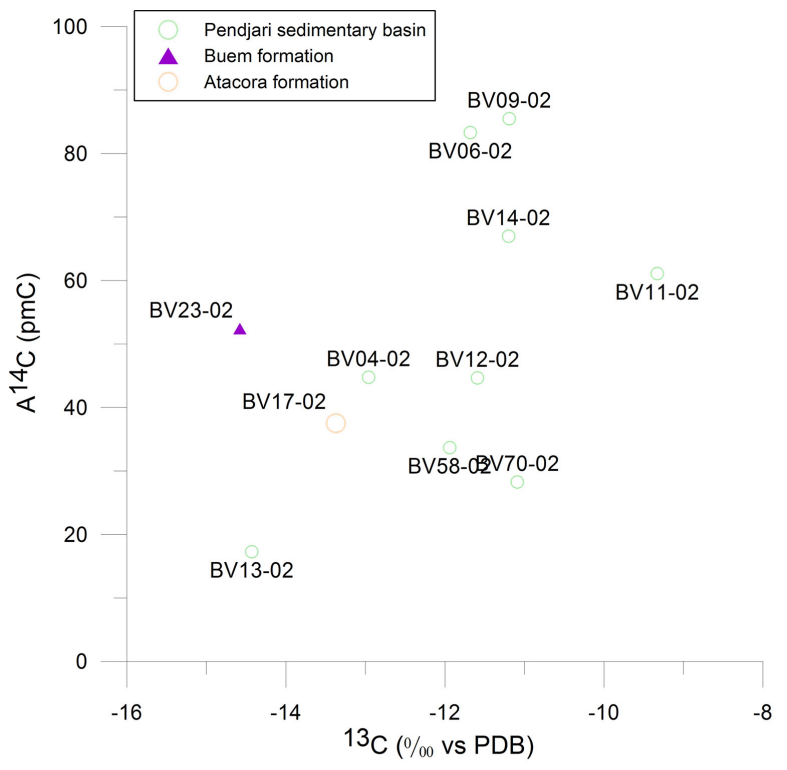

(a)

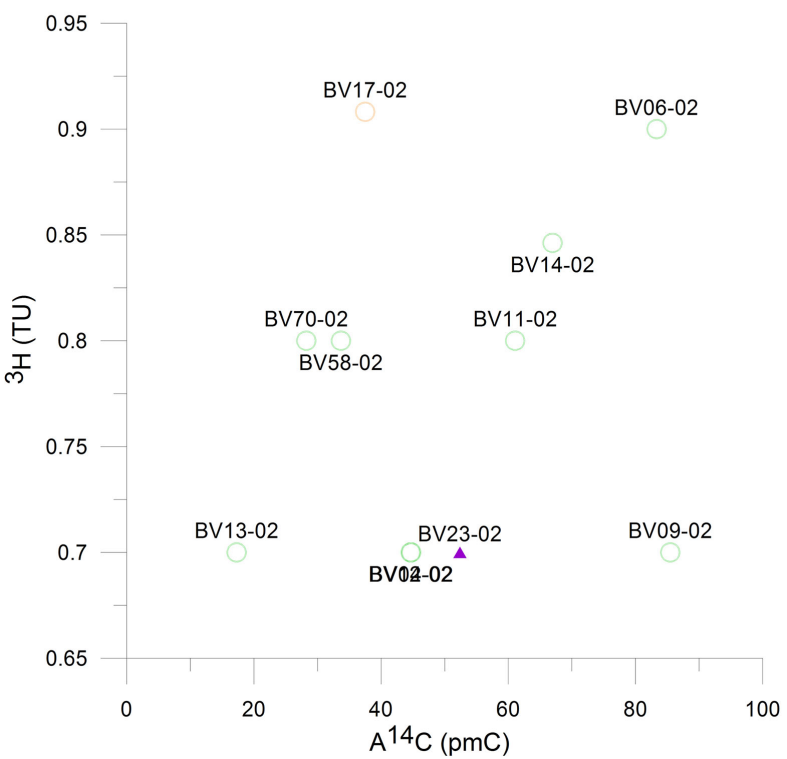

(b)

Figure 5. $\mathrm{A}^{14} \mathrm{C} /{ }^{13} \mathrm{C}$ (a) and $3 \mathrm{H} / \mathrm{A}^{14} \mathrm{C}$; (b) relations in Volta river basin in Benin. 


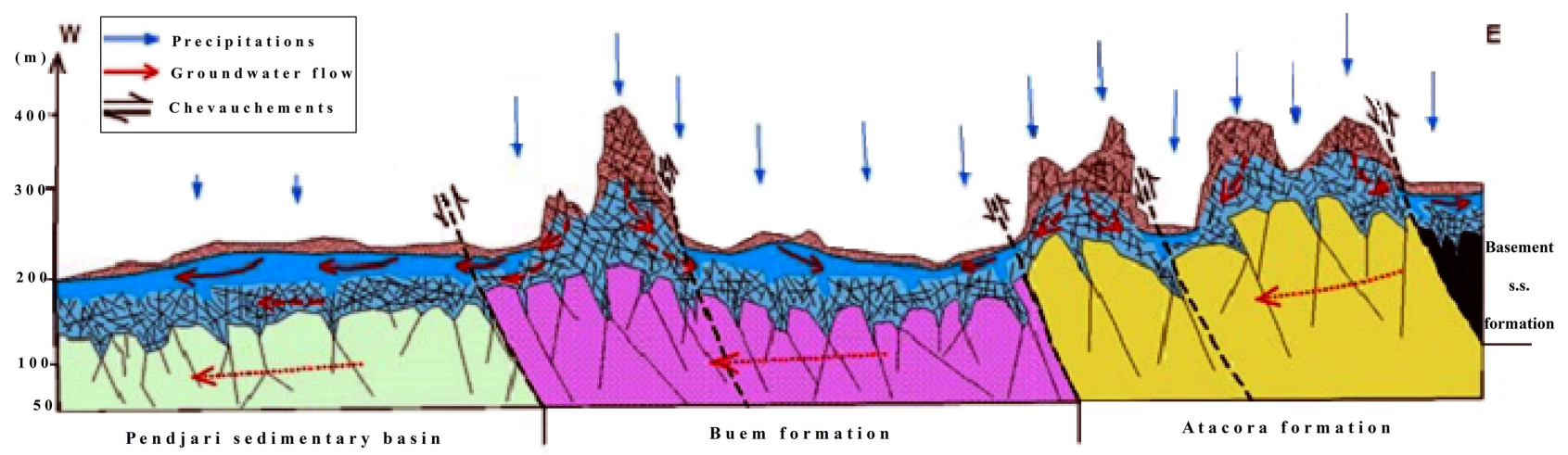

Figure 6. Conceptual diagram of the hydrogeological system within the Volta river basin in Benin.

Table 2. Groundwater age calculation (a) according to different correction models: [47] [48] [49] [50] [51] IAEA [52] and [53].

\begin{tabular}{|c|c|c|c|c|c|c|c|c|c|}
\hline Sample & Aquifer & \multirow{2}{*}{ Tamers } & \multirow{2}{*}{ Pearson } & \multirow{2}{*}{ Mook } & \multirow{2}{*}{ F \& G } & \multirow{2}{*}{ AIEA } & \multirow{2}{*}{ Evans } & \multirow{2}{*}{ Eichinger } & \multirow{2}{*}{$\begin{array}{c}\text { brut } \\
\mathrm{nc}\end{array}$} \\
\hline number & (formation) & & & & & & & & \\
\hline BV13 & Pendjari & 10,013 & 11,407 & 14,314 & 12,070 & 14,969 & 11,184 & 11,233 & 14,509 \\
\hline BV70 & Pendjari & 5797 & 5172 & 8502 & 5132 & 8665 & 4708 & 4518 & 10,450 \\
\hline BV58 & Pendjari & 4249 & 4329 & 7600 & 4371 & 7835 & 3940 & 3859 & 8997 \\
\hline BV12 & Pendjari & 1976 & 1752 & 5041 & 1738 & 5264 & 1337 & 1207 & 6666 \\
\hline BV04 & Pendjari & 1219 & 2657 & 6219 & 3353 & 6281 & 2365 & 2395 & 6647 \\
\hline BV11 & Pendjari & Actuel & Actuel & 1266 & Actuel & 891 & Actuel & Actuel & 4074 \\
\hline BV14 & Pendjari & Actuel & Actuel & 1378 & Actuel & 1674 & Actuel & Actuel & 3316 \\
\hline BV06 & Pendjari & Actuel & Actuel & Actuel & Actuel & 196 & Actuel & Actuel & 1510 \\
\hline BV09 & Pendjari & Actuel & Actuel & Actuel & Actuel & Actuel & Actuel & Actuel & 1298 \\
\hline BV23 & Buem & 1657 & 2325 & 4768 & 2660 & 5861 & 2106 & 2014 & 5341 \\
\hline BV17 & Atacora & 3437 & 4374 & 7441 & 4831 & 7892 & 4085 & 4094 & 8106 \\
\hline
\end{tabular}

\section{Conclusions}

The isotopes of radiocarbon, of tritium and stable isotopes of oxygen-18 and deuterium in the groundwater of the Volta river basin in Benin have been determined for a better understanding of the recharging source in the shallow aquifer system. Tritium concentrations, although generally low, are very close to current levels of precipitation and show that modern recharging occurs. Radiocarbon and tritium data led to the identification of groundwater with a long residence time of $10 \mathrm{ka}$.

The groundwater in this basin is characterized by $\mathrm{Ca}^{2+}$ and $\mathrm{Na}^{+}$ions and mainly by $\mathrm{HCO}_{3}^{-}$, which proves the interactions between groundwater and clay minerals and the processes of cation exchange and/or alteration of the silicates. The anthropogenic influence on groundwater through the intensive use of chemical fertilizers was also emphasized.

The groundwater system in the Volta river basin in Benin stands for the re- 
charging in modern climatic conditions. Meteoric variations in stable isotope compositions show that groundwater is not strongly affected by kinetic evaporation and it is due to natural variations in local and regional climatic conditions.

\section{Acknowledgements}

This study is carried out within the framework of the International Atomic Energy Agency (IAEA) Regional Project RAF-7011, Vienna, Austria. Our sincere thanks to the Agency, especially to Mr. Luis Espicia Toro, Mr. Luis Araguas and Mr. Eric J. Cole. We also thank all those who help us for the sampling campaigns and the laboratory analyzes.

\section{References}

[1] Martin, N., Eguavoen, I., Sandwidi, J.P. and Sessouma, A. (2008) Aspects hydrogéologiques et socio-légaux des eaux souterraines dans la satisfaction des besoins domestiques au niveau du bassin versant de la Volta. $13^{\text {th }}$ World Water Congress, Montpellier, 1-4 September 2008, 6 p.

[2] Banoeng-Yakubo, B., Yidana, S.M., Emmanuel, N., Akabzaa, T. and Asiedu, D. (2007) Analysis of Groundwater Quality Using Water Quality Index and Conventional Graphical Methods: The Volta Region, Ghana. Environmental Earth Sciences, 59, 867-879. https://doi.org/10.1007/s12665-009-0082-9

[3] Boubakar Hassane, A. (2010) Aquifères superficiels et profonds et pollution urbaine en Afrique: Cas de la communauté urbaine de Niamey (NIGER). Thèse de doctorat, Université Abdou Moumouni de Niamey, Niamey, 249 p.

[4] Totin, V.S.H., Afouda, A., Amoussou, A., Tumbulto, J. and Boko, M. (2010) Variabilité hydroclimatique et des ressources en eau de surface dans le bassin béninois de la Volta. In: Servat, E., et al., Ed., Proceedings of the Sixth World Friend Conference: Global Change: Facing Risks and Threats to Water Resources, IAHS Publication, Fez, Morocco, 164-171.

[5] Totin, V.S.H., Zannou, A., Amoussou, E., Afouda, A. and Boko, M. (2014) Progressive Aridity Impact on the Hydrological Regime in the Volta River Basin in Benin (West Africa). Hydrology in a Changing World: Environmental and Human Dimensions. Proceedings of FRIEND-Water 2014, Montpellier, 7-10 October 2014, 17-22.

[6] Barry, B., Obuobié, E., Andreini, M., Andah, W. and Pluquet, M. (2005) The Volta River Basin. Comprehensive Assessment of Water Management in Agriculture. Comparative Study of River Basin Development and Management. IWMI Report.

[7] Leemhuis, C., Jung, G., Kasei, R. and Liebe, J. (2009) The Volta Basin Water Allocation System: Assessing the Impact of Small-Scale Reservoir Development on the Water Resources of the Volta Basin, West Africa. Advances in Geosciences, 21, 57-62. https://www.adv-geosci.net/21/57/2009/ https://doi.org/10.5194/adgeo-21-57-2009

[8] Lemoalle, J. and De Condappa, D. (2009) Atlas de l'eau du bassin de la Volta. [Water Atlas of the Volta Basin.] CGIAR/CPWF, IRD, $96 \mathrm{p}$.

[9] Ouassa-Kouaro, M. (2008) Les déterminants socioculturels de la désertification dans l'Atacora Ouest au Bénin. Thèse de doctorat, Université Paris IV et Université d'Abomey-Calavi, Cotonou, 217 p.

[10] Idiéti, E.M. (2012) Variabilité hydro-climatique dans le bassin versant de la Pendjari (Nord-Ouest du Bénin). Thèse de Doctorat, Université d'Abomey-Calavi, Cotonou, 
Bénin, $229 \mathrm{p}$.

[11] Le Barbé, L., Alé, G., Millet, B., Texier, H., Borel, Y. and Gualde, R. (1993) Les ressources en eau superficielles de la république du Bénin. Edition Orstom, Paris, France, $540 \mathrm{p}$.

[12] Achidi, J., Bourguet, L., Elsaesser, R., Legier, A., Paulvé, E. and Tribouillard, N. (2012) Notice explicative de la carte hydrogéologique du Bénin: carte du bassin sédimentaire de la Volta à l'échelle du 1/200 000. Thechnical Report, GIZ Germany et DGEau, Cotonou, Benin, $39 \mathrm{p}$.

[13] Vissin, E.W. (2007) Impact de la variabilité climatique et de la dynamique des états de surface sur les écoulements du bassin béninois du fleuve Niger. Thèse de Doctorat, Université de Bourgogne, Dijon, France.

[14] Affaton, P. (1975) Etude geologique et structurale du NordOuest du Dahomey, du Nord du Togo, et du Sud-Est de la Haute Volta. Travaux Laboratoire Sciences Terre Bulletin, 10, 201.

[15] Affaton, P., Sougy, J. and Trompette, R. (1980) The Tectono-Stratigraphic Relationships between the Upper Precambrian and Lower Paleozoic Volta Basin and the Pan-African Dahomeyide Orogenic Belt West Africa. American Journal of Science, 280, 224-248. https://doi.org/10.2475/ajs.280.3.224

[16] Affaton, P., Aguirre, L. and Ménot, R.P. (1997) Thermal and Geodynamic Setting of the Buem Volcanic Rocks near Tiélé, Northwest Bénin, West Africa. Precambrian Research, 82, 191-209. https://doi.org/10.1016/S0301-9268(97)80686-9

[17] Technoexport (1980) La constitution et les substances utiles de la République Populaire du Bénin entre les 10ème et 11ème parallèles de latitude nord. Rapport Office Béninois des Mines, Cotonou.

[18] IRB Istituto Recherche Breda (1982) Etude de cartographie géologique et de prospection minière de reconnaissance au Nord du $11^{\text {ème }}$ parallèle. Final Report, OBEMINES, Cotonou.

[19] Attoh, K., Dallmeyer, R.D. and Affaton, P. (1997) Chronology of Nappe Assembly in the Pan-African Dahomeyide Orogen, West Africa: Evidence from 40Ar/39Ar Mineral Ages. Precambrian Research, 82, 153-171. https://doi.org/10.1016/S0301-9268(96)00031-9

[20] El-Hadj Tidjani, M., Affaton, P., Louis, P. and Socohou, A. (1997) Gravity Characteristics of the Pan-African Orogen in Ghana, Togo and Benin (West Africa). Journal of African Earth Sciences, 24, 241-258. https://doi.org/10.1016/S0899-5362(97)00041-9

[21] Ganade, C.E., Cordani, U.G., Agbossoumounde, Y., Caby, R., Basei, M.A.S., Weinberge, F.R. and Sato, K. (2016) Tightening-Up NE Brazil and NW Africa Connections: New U-Pb/Lu-Hf Zircon Data of a Complete Plate Tectonic Cycle in the Dahomey Belt of the West Gondwana Orogen in Togo and Benin. Precambrian Research, 276, 24-42. https://doi.org/10.1016/j.precamres.2016.01.032

[22] Boukari, M. (2007) Hydrogéologie de la république du Bénin (Afrique de l'ouest). Africa Geosciences Revue, 14, 303-328.

[23] Kalsbeek, F., Affaton, P., Ekwuemec, B., Frei, R. and Thrane, K. (2012) Geochronology of Granitoid and Metasedimentary Rocks from Togo and Benin, West Africa: Comparisons with NE Brazil. Precambrian Research, 196-197, 218-233. https://doi.org/10.1016/j.precamres.2011.12.006

[24] Wright, J.B., Hastings, D.A., Jones, W.B. and Williams, H.R. (1985) Geology and Mineral Resources of West Africa, Vol. 187. Allen \& Unwin, London. 
[25] El-Fahem, T. (2008) Hydrogeological Conceptualisation of a Tropical River Catchment in a Crystalline Basement Area and Transfer into a Numerical Groundwater Flow Model, Case Study for the Upper Ouémé Catchment in Benin. PhD Thesis, Bonn, 157 p.

[26] Agbossoumondé, Y., Menot, R.P. and Guillot, S. (2001) Metamorphic Evolution of Neoproterozoic Eclogites from South Togo (West Africa). Journal of African Earth Sciences, 33, 227-244. https://doi.org/10.1016/S0899-5362(01)80061-0

[27] Agbossoumondé, Y., Guillot, S. and Menot, R.P. (2004) Pan-African Subduction-Collision Event Evidenced by High-P Coronas in Metanorites from the Agou Massif (Southern Togo). Precambrian Research, 135, 1-21. https://doi.org/10.1016/j.precamres.2004.06.005

[28] Tairou, M.S. (2006) La tectonique tangentielle panafricaine au Nord-Togo. Thèse de Doctorat, Université de Lomé 135, 401 p.

[29] Acheampong, S.Y. and Hess, J.W. (2000) Origin of the Shallow Groundwater System in the Southern Voltaian Sedimentary Basin of Ghana: An Isotopic Approach. Journal of Hydrology, 233, 37-53. https://doi.org/10.1016/S0022-1694(00)00221-3

[30] Prakla Seismos, Gmbh (1984) The 30 Well Drilling Project. Internal Report, Catholic Diocese of Accra, Accra, $40 \mathrm{p}$.

[31] Acheampong, S.Y. and Hess, J.W. (1998) Hydrogeologic and Hydrochemical Framework of the Shallow Groundwater System in the Southern Voltaian Sedimentary Basin of Ghana. Hydrogeology Journal, 6, 527-537. https://doi.org/10.1007/s100400050173

[32] Buckley, D.K. (1986) Report on Advisory Visit to Wateraid Projects in Ghana. Unpublished Report, British Geological Survey, Hydrogeology Research Group, Wallingford, $56 \mathrm{p}$.

[33] Freeze, R.A. and Cherry, J.A. (1979) Groundwater. Prentice Hall, Englewood Cliffs.

[34] Penna, D., Stenni, B., Wrede, S., Bogaard, T.A., Gobbi, A., Borga, M., Fischer, B.M.C., Bonazza, M. and Charova, Z. (2010) On the Reproducibility and Repeatability of Laser Absorption Spectroscopy Measurements for ${ }^{2} \mathrm{H}$ and ${ }^{18} \mathrm{O}$ Isotopic Analysis. Hydrology and Earth System Sciences, 7, 2975-3014. https://doi.org/10.5194/hessd-7-2975-2010

[35] Thatcher, L.L., Janzer, V.J. and Edwards, R.W. (1977) Methods for Determination of Radioactive Substances in Water and Fluvial Sediments. In: Techniques of Water Resources Investigations, U.S. Geological Survey, Washington DC, 79-81.

[36] Stuiver, M. and Polach, H.A. (1977) Discussion: Reporting of ${ }^{14} \mathrm{C}$ Data. Radiocarbon, 19, 355-363.

[37] Kortatsi, B.K., Anku, Y.S.A. and Anornu, G.K. (2009) Characterization and Appraisal of Facets Influencing Geochemistry of Groundwater in the Kulpawn Sub-Basin of the White Volta Basin, Ghana. Environmental Geology, 58, 1349-1359. https://doi.org/10.1007/s00254-008-1638-9

[38] Adomako, D., Osae, S., Akiti, T.T., Faye, S. and Maloszewski, P. (2011) Geochemical and Isotopic Studies of Groundwater Conditions in the Densu River Basin of Ghana. Environmental Earth Sciences, 62, 1071-1084. https://doi.org/10.1007/s12665-010-0595-2

[39] Huneau, F. and Travi, Y. (2008) The Miocene Aquifer of Valreas, France. In: Edmunds, W.M. and Shand, P., Eds., Natural Groundwater Quality, Blackwell Publishing, London, 287-305. https://doi.org/10.1002/9781444300345.ch13 
[40] Huneau, F., Dakoure, D., Celle-Jeanton, H., Vitvar, T., Ito, M., Traore, S., Compaore, N.F., Jirakova, H. and Le Coustumer, P. (2011) Flow Pattern and Residence Time of Groundwater within the South-Eastern Taoudeni Sedimentary Basin (Burkina Faso, Mali). Journal of Hydrology, 409, 423-439. https://doi.org/10.1016/j.jhydrol.2011.08.043

[41] Dossou-Yovo, E.R., Brüggemann, N., Ampofo, E., Igue, A.M., Jesse, N., Huat, J. and Agbossou, E.K. (2016) Combining No-Tillage, Rice Straw Mulch and Nitrogen Fertilizer Application to Increase the Soil Carbon Balance of Upland Rice Field in Northern Benin. Soil \& Tillage Research, 163, 152-159. https://doi.org/10.1016/j.still.2016.05.019

[42] Lucas, L.L. and Unterweger, M.P. (2000) Comprehensible Review and Critical of the Half-Life of Tritium. Journal of Research of the National Institute of Standards and Technology, 105, 541-549.

[43] Mook, W.G. (2001) Isotopes de l'environnement dans le cycle hydrologique. Vol, 1, 81-92.

[44] Chéry, L. (2006) Qualité naturelle des eaux souterraines. Méthode de caractérisation des états de référence des aquifères français, Guide technique. BRGM Édition, 238, 90 .

[45] Abid, K., Hadj Ammar, F., Chkir, N. and Zouari, K. (2011) Relationship between Senonian and Deep Aquifers in Southern Tunisia. Quaternary International, 257, 13-26. https://doi.org/10.1016/j.quaint.2011.09.022

[46] Fontes, J.C., Andrews, J.N., Edmunds, W.M., Guerre, A.L. and Travi, Y. (1991) Paleorecharge by the Niger River (Mali) Deduced from Groundwater Geochemistry. Water Resources, 27, 199-214. https://doi.org/10.1029/90WR01703

[47] Tamers, M.A. (1975) Validity of Radiocarbon Dates on Groundwater. Surveys in Geophysics, 2, 217-239. https://doi.org/10.1007/BF01447909

[48] Fontes, J.C. and Garnier, J.M. (1979) Determination of the Initial Activity of the Total Dissolved Carbon a Review of the Existing Models and a New Approach. Water Resources Research, 12, 399-413. https://doi.org/10.1029/WR015i002p00399

[49] Evans, G.V., Otlet, R.L., Downing, A., Monkhouse, R.A. and Rae, G. (1979) Some Problems in the Interpretation of Isotope Measurements in United Kingdom Aquifers. Isotope Hydrology II, IAEA, Vienna, 679-708.

[50] Ingerson, E. and Pearson, F.J. (1964) Estimation of Age and Rate of Motion of Groundwater by ${ }^{14} \mathrm{C}$ Method. In: Miyake, Y. and Koyama, T., Eds., Recent Researches in Field of Hydrosphere, Atmosphere and Nuclear Geochemistry, Maruzen, Tokyo, 263-283.

[51] Eichinger, L. (1983) A Contribution to the Interpretation of ${ }^{14} \mathrm{C}$ Groundwater Ages Considering the Example of a Partially Confined Sandstone Aquifer. Radiocarbon, 25, 347-356. https://doi.org/10.1017/S0033822200005634

[52] Salem, O., Visser, J.H., Dray, M. and Gonfiantini, R. (1980) Groundwater Flow Patterns in the Western Lybian Arab Jamahiriaya. In: Arid-Zone Hydrology: Investigation with Isotope Techniques, IAEA, Vienna, 165-179.

[53] Mook, W.G. (1980) Carbon-14 in Hydrogeological Studies. In: Fritz, P. and Fontes, J.C., Eds., Handbook of Environmental Isotopes Geochemistry 1, Elsevier, Amsterdam, 1-74. https://doi.org/10.1016/B978-0-444-41780-0.50008-0

[54] Gasse, F. (2000) Hydrological Changes in the African Tropics since the Last Glacial Maximum. Quaternary Science Reviews, 19, 189-211. https://doi.org/10.1016/S0277-3791(99)00061-X 